\title{
Employees Creativity Not Required for Employees in the Television Industry?
}

\author{
Kirana Kemala Dewi, Tiarapuspa, Safnita, Andreas Wahyu Gunawan* \\ Faculty of Economics and Business \\ Universitas Trisakti \\ Jakarta, Indonesia \\ *andreaswg@trisaksi.ac.id
}

\begin{abstract}
This paper was to investigate the impact of transformational leadership and perceived organizational support on employee's creativity in PT. Omni Intivision. Data obtained directly through a questionnaire submitted to 117 respondents, namely to employees in the television industry. The research design used is hypothesis testing. The analytical method used in this study is the structural equation sample (SEM) using the Amos program. The results of this study are that there is a positive influence between transformational leadership on employee creativity. Meanwhile, perceived organizational support does not affect employee creativity.
\end{abstract}

Keywords-transformational leadership, perceived organizational support, employees creativity

\section{INTRODUCTION}

Industrial revolution 4.0 (four points zero) is the fourth phase of the course of the industrial revolution, which began in the 18th century with very rapid changes related to all dimensions of life with the existence of digitalization of the life sector, including in the television industry. The television industry functions as a news and entertainment messenger through audio-visuals where information conveyed through images and sound. So much public interest in television media, so that makes a lot of television stations popping up over time. Originally Indonesia only had one television station, namely TVRI (Televisi Republik Indonesia); besides TVRI there are TPI, RCTI, SCTV, ANTV, INDOSIAR, TV ONE, and many more television stations the other. The competition between television station companies is undoubtedly inevitable. Therefore, creative human resources are needed. Human resources have a major role in every company activity to survive in facing the challenges of competition. Employees Creativity has emerged as a possible source of competitive advantage because it enhances organizational performance and increases success and survival, based on its ability to create new knowledge and innovations [1,2].

Employees' creativity is a way to generate new ideas that are useful [3]. Creativity comes from thinking, skills, and expertise based on formal education and experience in each person [4]. Creativity defined as a way to create something valuable and useful, ideas, procedures, and processes by individuals who work in an organization [5]. Every organization needs creative human resources because creativity has become a necessity of various tasks and jobs [6,7] Employees' creativity is very important because creativity can handle problems that create superior performance [8,9]. So the employee's creative attitude will add to the organization's value. Factors that support employee creativity are transformational leadership and perceived organizational support

\section{LITERATURE REVIEW}

Transformational leadership can support employees' creativity because, specifically, transformational leadership is closely related to creativity. Transformational leadership inspires subordinates to work beyond their abilities [10]. This leadership includes employees, so they feel proud to be valued. Transformational leadership has 4 (four) dimensions, namely: idealized influence, inspirational motivation, intellectual stimulation, and individualized consideration [11]. In addition to transformational leadership, other factors can increase employee creativity, namely perceived organizational support.

Perceived organizational support can improve employee creativity through commitment and employee concern for the organization also explain perceived organizational support as the sensitivity and perception of employees regarding the extent to which their involvement is valued and recognized by the organization $[12,13]$. With the support of the organization, employees will feel protected and trust the organization.

Previous research on employee creativity in the Jordanian banking sector through the mediating effect of perceived organizational support in which the results show that transformational leadership positively affects several dimensions of employee creativity and seen organizational support. However, perceived organizational support was not significantly related to several dimensions of employee creativity. Also, the mediating effect of perceived organizational support on the relationship between transformational leadership and several dimensions of employee creativity found to be insignificant. 
Transformational leadership can create a climate where creative ideas are more likely to arise by motivating followers to develop new ideas, show confidence and not blame them when new ideas fail [14]. Some researchers have shown that transformational leadership has an essential role in providing support and encouragement to employees, to engage employees, and to show their creativity [15-17]. Thus, it shows that transformational leadership positively influences employees' creativity. Perceived organizational support is the employee's perception of their commitment to the organization, which engagement can improve performance through employee creativity [18]. Thus, perceived organizational support also positively influences employee creativity.

\section{METHODS}

This study refers to research that has been done by Ayoub et al [19]. This study was conducted to examine the effect of transformational leadership, perceived organizational support, and orientation learning on employee creativity.

The scale technique used in this study is a Likert scale from 1 to 5 , where $1=$ strongly disagree, $2=$ disagree, $3=$ quite agree, $4=$ agree, and $5=$ strongly agree. Independent variables are transformational leadership and perceived organizational support. And the dependent variable in this study is employee's creativity. This research collected data directly to answer the problem and research objectives. Thus, the data used are primary data, data collection is done by distributing questionnaires. The unit of analysis used is an employee. Data obtained by distributing questionnaires. The number of samples in this study were 117 respondents. Transformational leadership variables, perceived organizational support, and employees' creativity and validity, can be seen directly in Table 1 .

TABLE I. VALIDITY AND RELIABILITY TEST RESULTS

\begin{tabular}{|c|c|c|c|c|}
\hline No. & Statement Items & p-value & Cronbach's Alpha & Decision \\
\hline \multicolumn{5}{|c|}{ Transformational Leadership Variable } \\
\hline 1 & I feel proud to be associated with the leadership. & 0.777 & \multirow{7}{*}{0.733} & \multirow{7}{*}{ Valid and Reliable } \\
\hline 2 & I have confidence in the leadership. & 0.616 & & \\
\hline 3 & The leader has a mission that he spread to me. & 0.633 & & \\
\hline 4 & The leader always expresses satisfaction when his expectations are met. & 0.501 & & \\
\hline 5 & I have confidence in the values given by the leadership. & 0.549 & & \\
\hline 6 & The leadership has shown unusual competence. & 0.613 & & \\
\hline 7 & The leader appreciates my achievements. & 0.647 & & \\
\hline 8 & The chairman set the standard for my work. & 0.815 & \multirow{3}{*}{0.670} & \multirow{3}{*}{ Valid and Reliable } \\
\hline 9 & The leadership is always optimistic in discussing the company's future. & 0.651 & & \\
\hline 10 & I have trust in the leadership. & 0.720 & & \\
\hline 11 & I was encouraged to be smart in solving problems. & 0.787 & \multirow{3}{*}{0.606} & \multirow{3}{*}{ Valid and Reliable } \\
\hline 12 & I am encouraged to give an opinion accompanied by reasons that make sense. & 0.677 & & \\
\hline 13 & Leaders encourage employees to dare to convey ideas. & 0.780 & & \\
\hline 14 & Leaders always pay attention to employees, especially if they encounter difficulties. & 0.552 & \multirow{6}{*}{0.654} & \multirow{6}{*}{ Valid and Reliable } \\
\hline 15 & The leader always helps what becomes difficult and how to overcome it. & 0.693 & & \\
\hline 16 & Leaders always give appreciation when employees do a good job. & 0.621 & & \\
\hline 17 & The leadership always provides supervision and assistance to every employee. & 0.637 & & \\
\hline 18 & My leader is an active listener. & 0.568 & & \\
\hline 19 & Leaders always support the development of employees themselves. & 0.559 & & \\
\hline \multicolumn{5}{|c|}{$\begin{array}{c}\text { Perceived Organizational Support Variable } \\
\end{array}$} \\
\hline 1 & Procedural justice is applied consistently. & 0.872 & \multirow{3}{*}{0.727} & \multirow{3}{*}{ Valid and Reliable } \\
\hline 2 & I feel justice is free from deviations. & 0.763 & & \\
\hline 3 & I get justice for my work. & 0.777 & & \\
\hline 4 & The chairman respects my opinion. & 0.527 & \multirow{3}{*}{0.620} & \multirow{3}{*}{ Valid and Reliable } \\
\hline 5 & The leadership cares about employee welfare. & 0.605 & & \\
\hline 6 & The leader considers what the employees' goals and values are. & 0.524 & & \\
\hline \multicolumn{5}{|c|}{ Employees Creativity Variable } \\
\hline 1 & Leaders suggest new ways to achieve goals. & 0,800 & \multirow{3}{*}{0.626} & \multirow{3}{*}{ Valid and Reliable } \\
\hline 2 & Leaders suggest new ideas that are practical for improving performance. & 0.807 & & \\
\hline 3 & I was encouraged to fight for the ideas they have. & 0.656 & & \\
\hline
\end{tabular}

Source: Amos processing data resuls

Data analysis method in this research is structural equation sampling (SEM) which is used to analyse the relationship or influence of independent variables on the dependent variable that forms the path. In the structural equation sampling analysis program used is Amos.

TABLE II. MOdEL FeAsiBILITY TEST RESUlt

\begin{tabular}{|l|l|l|l|}
\hline Goodness of fit index & Criteria (cut-off value) & Indicator Value & Conclusion \\
\hline Chi-Square $\left(\mathrm{X}^{2}\right)$ & Close to 0 & 44,966 & Poor of Fits \\
\hline Probability & $\geq 0,05$ & 0,006 & Poor of Fits \\
\hline NFI & $\geq 0,90$ & 0,741 & Marginal of Fits \\
\hline TLI & $\geq 0,90$ & 0,971 & Good of Fits \\
\hline CFI & $\geq 0,90$ & 0,848 & Marginal of Fits \\
\hline RMSEA & $\geq 0,10$ & 0,087 & Marginal of Fits \\
\hline \multicolumn{4}{|l|}{ Source: Amos data processing result }
\end{tabular}




\section{RESULTS AND DISCUSSION}

\section{A. Results}

This study aims to determine the effect of transformational leadership and perceived organizational support on employee creativity. Table 2 results of the goodness of fits test where this test determines the data that used IN, NFI, TLI, CFI, and RMSEA measurements. Thus, the model can be used to test theoretical hypotheses.

Based on the results of hypothesis testing for a positive effect between transformational leadership on employee creativity is accepted. That is, the better transformational leadership in an organization will increase employee creativity. While in the second hypothesis, perceived organizational support does not affect employees' creativity, so the hypothesis is rejected. Even though employees feel organizational support, it does not affect employee creativity in an organization.

\section{B. Discussion}

The results of this study indicate that hypothesis 1 is supported which means transformational leadership affects employee creativity. Whereas, hypothesis 2 is rejected, which means perceived organizational support does not affect employees' creativity. So the results of these studies support the research conducted by Ayoub et al [19]. High organizational support cannot guarantee the high work creativity of employees, this is because employees have a tendency to follow their co-workers or are referred to as social conformity, as it is known that in the world of entertainment, closeness to co-workers is a matter that strongly supports one's creativity, let alone the millennial generation that lives in the 4.0 era, it has the characteristics of always being supportive and compact with its colleagues, so that the leader and co-worker become a source of sparring partner for an employee to spur creativity.

This research only examines the factors that influence employee creativity. Also, this research was only conducted on employees in television companies. Future studies could be done to test other factors that influence employee creativity in addition to transformational leadership. And can be done on employees in other industries besides the television industry.

\section{CONCLUSION}

This study provides an overview of the factors that influence employee creativity. Transformational leadership has a positive effect on employee's creativity. The better leadership in the organization will be very influential in motivating and increasing the creativity of its employees. Employees will feel valued and recognized so they can make them create new ideas that are creative in doing work.

\section{REFERENCES}

[1] M. Hyypiä and S. Parjanen, "Boosting Creativity with Transformationa Leadership in Fuzzy Front-end Innovation Processes," Interdisciplinary Journal of Information, Knowledge \& Management, vol. 8, 2013.

[2] H.I. Ibrahim, A. Isa and A.S. Shahbudin AS, "Organizational suppor and creativity: the role of developmental experiences as a moderato," Procedia Econ Financ., vol. 35, pp. 509-514, 2016

[3] J. Jyoti and M. Dev, "The impact of transformational leadership on employee creativity: the role of learning orientation,” J Asia Bus Stud. vol. 9 , pp. 78-98, 2015

[4] K.K. Dewi, S. Tiarapuspa and A.W. Gunawan, "Employees Creativity not required for employees in the television industry?" The Influe., pp. 1-5, 2019.

[5] R.W. Woodman, J.E. Sawyer, R.W. Griffin, S.E. Sawyer and R.W. Griffin, "Toward a Theory of Organizational Creativity, "Acad of Management Rev, vol. 18, no. 2, pp. 293-321, 1993.

[6] A.B. Abdallah and Y. Matsui, "The Impact of Lean Practices on Mass Customization and Competitive Performance of Mass-Customizing plants," Proc 20th Annu Prod Oper Manag Soc Conf., pp. 1-30, 2009.

[7] A.B. Abdallah, A.C. Phan and Y. Matsui, "Investigating the effects of managerial and technological innovations on operational performance and customer satisfaction of manufacturing companies," Int J Bus Innov Res., vol. 10, no. 2-3, pp. 153-183, 2016.

[8] D. Grewal, M. Levy and V. Kumar, "Customer experience managemen in retailing: anorganizing framework," J Retail, vol. 85, no. 1, pp. 1-14, 2009.

[9] Verhoef, P. C., Lemon, K. N., Parasuraman, A., Roggeveen, A., Tsiros, M., \& Schlesinger, L. A. (2009). Customer experience creation Determinants, dynamics and management strategies. Journal of retailing, 85(1), 31-41.

[10] M.F.Y. Cheung and C.-S. Wong, "Transformational leadership, leader support, and employee creativity," Leadersh Organ Dev J, vol. 32, no. 7 pp. 656-672, 2011.

[11] B.M. Bass and B.J. Avolio, Improving Organisational Effectiveness through Transformational Leadership. Thousand Oaks, CA: Sage, 1994.

[12] L. Shore and L. Tetrick, "The psychological contract as an explanatory framework in the employment relationship," J Organ Behav., vol. 91, 1994.

[13] J. Krishnan, Perceived Organisational Support - an Overview on Its, 2012

[14] D. Herrmann and J. Felfe, "Effects of leadership style, creativity technique and personal initiative on employee creativity," Br J Manag. vol. 25 , no. 2 , pp. 209-227, 2014.

[15] G. Gong, P. Rosa-Neto, F. Carbonell, Z.J. Chen, Y. He and A.C. Evans, "Age- and gender-related differences in the cortical anatomical network," J Neurosci., vol. 29, no. 50, pp. 15684-15693, 2009.

[16] T. Elkins and R.T. Keller, "Leadership in research and development organizations: A literature review and conceptual framework," Leadersh Q, vol. 14, no. 4-5, pp. 587-606, 2003.

[17] S.J.Shin and J.M. Zhou, "Transformational leadership, conservation, and creativity: evidence from Korea," Acad Manag Journal, vol. 46, no. 6, pp. 703-714, 2003.

[18] M. Porkiani, M. Beheshtifar and M. Nekoie-moghadam, "Succession Planning In Iranian Governmental Agencies," Management, vol. 6, no. 12, pp. 736-741, 2010.

[19] H.F. Ayoub, A.B. Abdallah and T.S. Suifan, "The effect of supply chain integration on technical innovation in Jordan: The mediating role of knowledge management," Benchmarking, vol. 24 , no. 3, pp. 594-616, 2017. 